\title{
Elements of organizational communication
}

\author{
Michal Kolcun 1 , Bianca Teodorescu², Daniela Gîfu ${ }^{3}$ \\ ${ }^{1}$ Technical University of Košice, Bayerova 1, 08001, Prešov, Slovakia \\ 2University of Craiova, 13 A. I. Cuza Street, Craiova, 200585, Romania \\ 3"Alexandru Ioan Cuza" University of laşi, Bd. Carol I no. 11, 700506, Iaşi, Romania \\ E-mail address: bosunpetre@yahoo.com
}

\begin{abstract}
The organizational communication represents an arbitrated process in which the message is sent to the organization through a planning process and development strategy. The concept of communication has the role to make the connection between people. Human relations are in fact organizational communication interaction; they represent a universal concept because everything in the world is communicated. In a global setting, the information can be common, but also they can adapt in function of the immediate reality. One of the effects of the mass media is to develop the human relations and cultural relations by creating a connection between the members of different community. Communication is an essential condition in human evolution. A communication interaction generates significances, but any human behavior can be seen as an intentional act. A man's experience of many types of interactions represents his personal system (with subjective preferences and objective preferences). The interaction is a complex system and is represented by the state of homeostasis. Social interaction assumes a communication interaction with social-organizational facts: any actions is based on an idea and express the communication idea.
\end{abstract}

Keywords: communication; management; organizational communication

\section{INTRODUCTION}

Our society is made of a great number of factors and variables, a general study is based on risks such as losing sight of important elements or even deviating from the initial goals. The media and the advertising represent two of the most important components of the modern society. Both have the power to establish the people's acces of information and the exposition to persuasive messages and influence.

But how the messages are submitted through mass media? All the media's mechanism is known as advertising that has the purpose of influencing and persuading the target public. The transmission of the messages through the press is a more difficult mission as to the interactive means of communication.

\section{BASIC ELEMENTS OF ORGANIZATIONAL COMMUNICATION}

The communication is an institutional system organized by interdependent elements which they exist in an interaction (production, reception, processing, the transmission of 
meanings-Information). Thus, the system appears as part of the knowledge held by a subject in achieving to a research goal (Borowski, 2013; Traistaru \& Avram, 2014). The limits of the system are determined by the research's purpose. All the elements and connections are in fact components of the system; it is important to know that elements represent the base of the system and connections represent the relation between the elements in the system. When a system is defined, it is necessary to have a prior information regarding the phenomenon and a rigorous formulation about the object of the research. Communication is based on components like: source-communicator (the producer), significances (the message), context, canal, code, signal, noise and target-communicator (the consumer).

This form of communication creates the transfer between significances and Information. The communications and informational connections ensure intern and external adaptation and stability to the system. Communication is not an isolated system. The intern and external connection of the communication system varies over time and have the capacity to enhance his own parameters, structure and model of behaviour. As any complex and dynamic system, communication has a general line of conduct determined by the informational connections which they are formed in the process of communication and have unitary, coherent and cohesive character. The base of the informational connection is represented by the messages and has an informational action. The behaviours in the system are dependent on the information that is circulated on. Communication can be stable especially when she is more isolated from the information and the ex-system influences. A communication structure is well defined and represents a strong organization of elements in the system. The organizational communication involves the process of planning and development of strategies in a manner to reach the desired results (Vlăduţescu, 2013; Gîfu \& Teodorescu, 2014).

Communication has different forms: indirect, informative, persuasive, analog and digital. All these forms represent human communication, the bond between groups of people whose interests and concerns for the overall behaviour or specific groups that constitute the receptor.

Interaction is the way in which a human reacts in activities, actions and different type of behaviour (verbal, artistic, etc). In the individual or collective existence, the communication represents an important factor. From this perspective, the process of communication has a major impact above the social, cultural and economic activity of the society. A short history and structural analyses of this process are necessary in marketing and advertising. The human communication is representing the first step in creating the advertising messages. For the communication advertising to persuade a large number of people, it must rely on the mass communication (Yates, 1992; Vlăduţescu, 2008; Vlăduţescu, 2014).

The objectives of communication can be determined only when knowing individual communication partner in the act of communication is possible. These interactions can be: adversarial (when the answer is based only on the question), disqualification (the answer is not compatible with the question) and mystification (the answer is maybe a lie). They are produced in the system. A communication interaction possesses and generates significances, but if it is analysed outside the system, it may be dispossessed from it's real purpose.

A simple behaviour is just an intentional context in the system. The intentional context is a form of culture.

In the professional act, a person habituates his achievements in his own personal life, for example: a doctor will acquire his role of a doctor and the professional medical language (he treats the others like his own patients). In this situation, the interaction is more complex. Each person has the experience of several types of interaction that is linked in a personal system. The human behaviour can be detected by the analyse of the system in a manner to give coherence. 
Every system has a state of homeostasis. Interaction as a complex system is framed the effort of communication actors in maintaining his state with a minimum effort. Any excess or avoidance of a report will be indications of breaking or balancing feedback or feedforward the homeostasis. For example: when a conversation about someone's health is intentionally diverted by a relative in which in one way or another he could be the target of the behaviour.

The damage of homeostasis occurs in the articulation of goals that directs the functions which are performed by the communicative interaction. Every system has as a main trend a state quo; it is a normal attitude in protecting the homeostasis, even in the terms of progress, this thing is indisputable (Grabara, Kolcun \& Kot, 2014; Bajdor \& Grabara, 2014). Although the trend is that the history to stay in the same place. An urge of history it may be decoded as a distortion of homeostasis. Communication is an ensemble of facts and language that the actors put in work the process regarding the establishment or modification of a poetry or psychic state, ideas, thoughts and feelings. In this process is taking place a transfer of significances messages: knowledge, ideas, feelings, beliefs and opinions.

All these target some modification regarding the behaviours, attitudes, value system, opinions or position. Orientation is the intentional part of communication and it consists in motivations and interests. Communication as an interactive construction implies practices of thoughts, knowledge and language. In the society, communication has a major impact in constitution, organization and function of it (Dima \& Vlăduţescu, 2012; Vlăduţescu \& Ciupercă, 2014). The social interaction gives coherence to the society and assumes a communication interaction: any action is based on a communication idea. The human relation's contain moderate the perception, faiths, attitudes and behavior, communicative interactions are at different levels of the social structure. In communication, the presence and the contact are in a tense relationship with needs, aspirations, interests, ideas and attitudes.

The technologies created by the human are in fact communication means, a man communicates his thoughts through any type of communication (verbal, nonverbal, sculpture, music). The technologies of the modern age are differentiated in a significant way from the previous communication means. The experience is what it makes the man to be ready to correlate with different type of communication technologies.

The culture has three fundamental stages: oral, visual and audio. The second stage is Galaxy Gutenberg (the pattern age) and the third is a Galaxy Marconi (electronics communication: cinema, radio and TV).

People are constantly in the need to control the environment, to act in function of their reality. Most of the media messages received daily are in fact general information, because of this bond in communication between man-mass media, the people are increasing their knowledge. The utility information represents a priority for the public. In function of their daily actives (cinema or theatre's schedule, urban transport, weather forecast, stock, etc.), people are ordering their life. A part of them have utility functions and others can be just a crisis, accident or unexpected events. Thus, the prospective vision of the mass media can help the population to collective mobilization, at improve the damages or preventing the unpleasant events. Mass media offers a large range of information about the public's concerns, needs and interests.

The role of the communication means is to obtain the information and to send them to the public. The mass media is a version of an event. Sometimes, the people take the received messages for granted without any reflection of it; the problem is that people are receiving a large information volume daily. The means of the communication are techniques extensions of people. The means are in fact messages that draw attention in a shocking-offensive modality to the importance of transmitting the message (contribution to any message). Through this system, the message is transformed, processed and highlighted by the communication means. 
The value of communication means is represented by the sent message's sum and its content is dependent on the technique structure.

One of the language particularities is that the convention can be renewed and modified with every verbal exchange (Shockley-Zalabak, 2011; Conrad \& Poole, 2011; Miller, 2014). The human communication is necessitating an emission and reception device controlled by the will. If the involuntary reflex signs (communication facts) can intercede in communication as a contradictory complement or as a language, then they are not representing an essential part. The human body has two systems: motor and phonic (it is a specialization of the motor system) and because of that, the language is expressed through gesture or talk (Constantinescu, Gîrboveanu \& Dumitraşcu, 2011; Pipas \& Sîrbu, 2014). These two systems have the same litheness and offer a variety of elementary symbols. For reception, the organism has three canals: tactile, visual and acoustic. The first two capture the emission of the motor system, and the last of the phonic system, tactile canal is capable to fulfill the other functions (for example in the communication with the blind or deaf people, but the function is limited, the physical contract is necessary). It is used in interpersonal communication without any material objection because the distance between the communicators is small. This canal does not adapt to the condition of the society and it can't create a language (Kot, Grabara \& Kolcun, 2014).

The ensemble created by the motor system and phonic system for emission (as part of language-communication) is creating a communication space with some bounds: impose by the visual activity and by the power of the voice. It is important to know that the language has a time limit. The language is a social construction that has to power to exceed the manipulation dimension. It does not exist a language without permanent structure or less sustainable, only in grammar. Information is confirmed or denied in the communication (Roşca, 2012; Smarandache \& Vlăduţescu, 2014; Craig, 2014; Gasderell, 2014).

A code is formed through a vocabulary and a set of rules in lexical elements though it is manages the significances. There are two types of codes: verbal codes and nonverbal codes. They act integrated and oriented and represents a part of the communication system. Any hyper-codification (understood as operation and a result of utilization in excess of many codes) increases the probability that the messages signification proceed in the communication flux to don't be decoded and interpreted in intentional staff by their producer. The fundamental function of the communication is the signification communization. For this, the communication system puts different signification codes (natural and artificial). The codes are language too. Communicators are using verbal codes and nonverbal codes.

In communication, a culture has specific language models with a statute and a role: the words used are different when we are addressed to a manager, a large or small public, to our friends or relatives (Kot \& Ślusarczyk, 2013; Kot \& Ślusarczyk, 2014). The used of these models transmit information about the attitude, feelings, intention. The formula that is addressed expresses a psychological and social distance between the communicators: in our culture we use the second person singular and the first name in our closer relations, informal, between the partners with the same statute and plural second person the second name and maybe the title, function or any other formula for the people with a higher statute or with the ones we have a distant relation.

\section{CONCLUSION}

The communication forms are interrelated and have common support. The verbal express is facilitated by the gesture and movement and banning them can produce communication 
disturbances. In an act of transmitting the information, the communication and the effects are representing mechanism known as advertising messages with the purpose to influence and persuading the target public.

\section{ACKNOWLEDGMENT}

This work was partially supported by the grant number $33 \mathrm{C} / 2014$, awarded in the internal grant competition of the University of Craiova.

\section{References}

[1] J. Yates, W. J. Orlikowski, Academy of management review 17(2) (1992) 299-326.

[2] Jason L. Powell, International Letters of Social and Humanistic Sciences 17(1) (2014) $1-60$

[3] Ştefan Vlăduțescu (2008). Mesaje şi texte gânditoare. Craiova: Editura Sitech.

[4] Andrzej Borowski, International Letters of Social and Humanistic Sciences 14 (2014) $33-41$.

[5] P. Shockley-Zalabak (2011). Fundamentals of organizational communication. Pearson Education.

[6] Gary L. Kreps (1990). Organizational communication: Theory and practice. New York: Longman.

[7] F. M. Jablin, L. Putnam (Eds.). (2000). The new handbook of organizational communication: Advances in theory, research, and methods. Sage Publications.

[8] Andrzej Borowski, International Letters of Social and Humanistic Sciences 14 (2014) 7-17.

[9] Ştefan Vlăduţescu, European Scientific Journal 9(32) (2013).

[10] Marian Siminică, Aurelia Traistaru, International Journal of Education and Research 1(12) 2013.

[11] A. Traistaru, M. Avram, International Letters of Social and Humanistic Sciences 13 (2014) 79-88.

[12] Florentin Smarandache, Ştefan Vlăduţescu (2014). Communication Neutrosophic Routes. Columbus, OH: Educational Publishing.

[13] K. Miller (2014). Organizational communication: Approaches and processes. Cengage Learning.

[14] C. Conrad, M. S. Poole (2011). Strategic organizational communication: in a global economy. John Wiley \& Sons.

[15] Andrzej Borowski, International Letters of Social and Humanistic Sciences 4 (2013) 70-74.

[16] Ștefan Vlăduțescu (2004). Studii de Psihologie generală şi Psihologie socială. Craiova: Editura Sitech. 
[17] M. W. Kramer (2014). Managing uncertainty in organizational communication. Routledge.

[18] D. Constantinescu, S. R. Gîrboveanu, E. Dumitraşcu (2011). Comunicare organizaţională. Editura Pro Univeritaria, Bucureşti.

[19] Ioan Constantin Dima, Ştefan Vlăduţescu (2012). Persuasion elements used in logistical negotiation: Persuasive logistical negotiation. Saarbrucken: LAP Lambert Academic Publishing.

[20] Alina Tenescu, Mirela Teodorescu, Communications in Applied Sciences 2(1) (2014).

[21] Ştefan Vlăduţescu (2013). What Kind of Communication Is Philosophy. Jokull.

[22] D. Pipas, J. Sirbu, A. Pipas, Acta Universitatis Bogdan Voda Series Oeconomica 16 (2014) 49-60.

[23] D. Pipas, M. Jaradat, Acta Universitatis Bogdan Voda Series Oeconomica 16 (2014) 39-48.

[24] Ştefan Vlăduţescu, American International Journal of Contemporary Research 3(10) (2013).

[25] M. G. Mangra, E. A. Cotoc, A. Traistaru, Journal of Studies in Social Sciences 6(1) (2013).

[26] Daniela Gîfu, Mirela Teodorescu, International Letters of Social and Humanistic Sciences 17 (2014) 119-127.

[27] Andrezj Borowski, International Letters of Social and Humanistic Sciences 2 (2014) 110-121.

[28] Florentin Smarandache, Ştefan Vlăduţescu (2014). Neutrosophic Emergences and Incidences. Saarbrucken: LAP Lambert Academic Publishing.

[29] Ioan Constantin Dima, Mirela Teodorescu, Daniela Gifu, International Letters of Social and Humanistic Sciences 20 (2014) 46-55

[30] Andrezj Borowski, International Letters of Social and Humanistic Sciences 3 (2013) 69-74.

[31] Ş. Vlăduţescu, E. M. Ciupercă (2013). Next Flood Level of Communication: Social Networks. Aachen: Shaker Verlag.

[32] Daniela Gîfu, Mirela Teodorescu, International Letters of Social and Humanistic Sciences 18 (2014) 48-57.

[33] Ștefan Vlăduțescu (2013). Principle of the Irrepressible Emergence of the Message. Jokull.

[34] Tomáš Hes, Anna Poledňáková, International Letters of Social and Humanistic Sciences 2 (2013) 18-31.

[35] Mohsen Mehrara, Masoumeh zirak, International Letters of Social and Humanistic Sciences 2 (2013) 32-38.

[36] Andrzej Borowski, International Letters of Social and Humanistic Sciences 3 (2013) 46-53. 
[37] Donovan A. McFarlane, International Letters of Social and Humanistic Sciences 4 (2013) 35-44.

[38] Kinga Dziwańska, International Letters of Social and Humanistic Sciences 7 (2013) 96-112.

[39] Mohsen Mehrara, Maysam Musai, International Letters of Social and Humanistic Sciences 8 (2013) 1-7.

[40] Colhon, M. (2013). Automatic Lexical Alignment between Syntactically Weak Related Languages. Application for English and Romanian. In Computational Collective Intelligence. Technologies and Applications (pp. 266-275). Springer Berlin Heidelberg.

[41] Janusz Grabara, Michal Kolcun, Sebastian Kot, International Journal of Education and Research 2(2) (2014).

[42] Mădălina Giorgiana Mangra, Elena Antoanela Cotoc, Aurelia Traistaru, A., Journal of Studies in Social Sciences 6(1) (2013).

[43] Dumitru Zamfir, Ştefan Vlăduţescu (2003). Percepţia şi audiopercepţia, o abordare cognitiv-constructiv-operaţioanală. Bucureşti: Editura Didactică şi Pedagogică.

[44] Sebastian Kot, Janusz Grabara, Michal. Kolcun, International Letters of Social and Humanistic Sciences 15 (2014) 1-6.

[45] J. H. Gasderell, International Letters of Social and Humanistic Science 22 (2014) $85-91$.

[46] Ștefan Vlăduțescu, International Letters of Social and Humanistic Sciences 7 (2014) 8-13.

[47] Max G. Craig, Journal of Studies in Social Sciences 8(1) (2014).

[48] Paula Bajdor, Iwona Grabara, Journal of Studies in Social Sciences 7(2) (2014).

[49] Jason L. Powell, International Letters of Social and Humanistic Sciences 7 (2014) 22-30.

[50] Agnieszka Ulfik, Stefan Nowak, Polish Journal of Environmental Studies 23(3) (2014).

[51] Ștefan Vlăduțescu, Journal of Sustainable Development Studies 6(1) (2014).

[52] Vlad Roşca, Theoretical and Applied Economics, 1(1) (2012) 127.

[53] Sebastian Kot, Beata Ślusarczyk, The Journal of American Business Review Cambridge (2014).

[54] Sebastian Kot, Beata Ślusarczyk, Applied Mechanics and Materials 309 (2013) 206-212.

[55] Petre Bosun, Janusz Grabara, International Letters of Social and Humanistic Sciences 14 (2014) 59-65.

[56] Jason L. Powell, International Letters of Social and Humanistic Sciences 16(2) (2014) 132-143.

[57] Ștefan Vlăduțescu, International Letters of Social and Humanistic Sciences 10 (2014) 100-106. 
[58] Jason L. Powell, International Letters of Social and Humanistic Sciences 16(2) (2014) 177-183.

[59] Mohsen Mehrara, Hamid Abrishami, Mostafa Boroujli, Mahan Amin, International Letters of Social and Humanistic Sciences 11 (2013) 76-83.

[60] Bahram Meihami, Hussein Meihami, International Letters of Social and Humanistic Sciences 3 (2014) 80-91.

[61] Rajesh K. Yadav, Nishant Dabhade, International Letters of Social and Humanistic Sciences 4 (2013) 49-69.

[62] Tomáš Hes, Alena Neradová, Karel Srnec, International Letters of Social and Humanistic Sciences 7 (2013) 55-75. 